\title{
Pengaruh Sosiologis Kemasyarakatan terhadap Karakter Keluarga
}

\author{
M. Zainuddin \\ Universitas Negeri Malang, Indonesia \\ Email: mohammad.zainuddin.fip@um.ac.id
}

\begin{abstract}
Abstrak: Pola kehidupan menurut ajaran agama Islam telah menggariskan untuk keteladan bagi seluruh umatnya khususnya pola kehidupan sosial kemasyarakatan seperti halnya dalam berumah tangga disunnahkan mencari tempat tinggal yang nyaman dan baik, bergaul dengan sesama muslim, serta berkegiatan sosial yang berdampak posistif, sebaliknya masih ada sebagian besar orang yang menerapkan pola kehidupan sosial kemasyarakatan yang tidak sesuai dengan Sunnah tersebut, sehingga banyak pengaruh keburukan dalam kehidupan bermasyarakat bahkan hal tersebut menjadi faktor utama timbulnya konflik atau masalah sosial yang berakibat ketidak seimbangnya pola kehidupan bermasyarakat serta berakibat banyaknya permasalahan keluarga, kenakalan anak bahkan
\end{abstract}

\begin{tabular}{l}
\hline Tersedia Online di \\
\hline http://journal.unublitar.ac.id/pendidikan \\
\hline lindex.php/Riset_Konseptual \\
\hline Sejarah Artikel \\
\hline Diterima pada : 06-07-2020 \\
Disetuji pada : 30-07-2020 \\
Dipublikasikan pada : 31-07-2020 \\
\hline Kata Kunci: \\
\hline Sosiologis Kemasyarakatan, Karakter \\
Keluarga, masalah sosial, masalah keluarga \\
DOI: \\
\hline http://doi.org/10.28926/riset_konseptual.v4i3.2 \\
63
\end{tabular}
kejahatan dalam keluarga dan masyarakat. Tujuan dalam penelitian ini yaitu penulis berkeinginan untuk mengetahui penyebab utama munculnya pengaruh sosiologis kemasyarakatan yang berdampak terhadap karakter keluarga serta dampaknya pada kehidupan bermasyarakat.kemudian penulis menggunakan pendekatan kualitatif melalui penerapan studi kasus dan menerapkan pemilihan mandiri untuk memilih peserta penelitian serta melakukan interview via daring untuk pengambilan seluruh data dalam kelengkapan penelitian. Proses analisa data yang diperoleh melalui lima tahapan yaitu: 1) Mengatur dan menyiapkan data untuk dianalisis; 2) membaca atau melihat semua data; 3) Mulai koding semua data; 4) menghasilkan deskripsi dan tema; 5) mendeskripsikan sebagai temuan penelitian ini. Hasil penelitian mengungkapkan bahwa karakter tauladan keluarga serta sikap buruk kehidupan sosial sangat dipengaruhi oleh pola pilihan hidup keluarga bersosial dalam masyarakat. Implikasi hasil penelitian ini sangat bermanfaat khususnya bagi keluarga baru yang akan memutuskan pindah tempat tinggal dari orangtuanya dan bagi orangtua yang akan memilihkan hunian baru bagi anaknya.

\section{PENDAHULUAN}

Sosiologi adalah studi tentang masyarakat. ilmu sosial yang melibatkan studi tentang kehidupan sosial orang, kelompok, dan masyarakat serta studi ilmiah tentang agregasi sosial, entitas yang melaluinya manusia bergerak sepanjang hidup mereka. sebuah masyarakat adalah sekelompok orang dengan wilayah, interaksi, dan budaya yang sama. Kelompok sosial terdiri dari dua orang atau lebih yang berinteraksi dan mengidentifikasi satu sama lain. Istilah "masalah sosial" biasanya digunakan untuk merujuk pada kondisi sosial yang mengganggu atau merusak masyarakat kejahatan, rasisme, dan sejenisnya Hal ini berfokus pada bagaimana dan mengapa orang memahami bahwa beberapa kondisi harus dipandang sebagai masalah sosial, yaitu, bagaimana mereka secara sosial membangun masalah sosial. Sosiologi sebenarnya memiliki dampak mendalam pada masyarakat baik secara terbuka maupun di belakang layar. Harus ada persepsi bahwa suatu kondisi atau perilaku perlu ditangani agar dapat dianggap sebagai masalah sosial. Komponen ini terletak pada pandangan konstruksionis sosial tentang masalah sosial (Rubington \& Weinberg, 2010). Dalam pandangan tersebut, ada banyak jenis kondisi dan perilaku negatif dan dianggap cukup negatif untuk memperoleh status masalah sosial; beberapa tidak menerima pertimbangan ini dan karenanya tidak menjadi masalah sosial; dan 
beberapa dianggap sebagai masalah sosial hanya jika warga negara, pembuat kebijakan, atau pihak lain meminta perhatian pada kondisi atau perilaku tersebut. Dan lagi Perhatian khusus diberikan kepada kelompok populasi dalam masyarakat kita yang diketahui memiliki kebutuhan khusus seperti anak-anak dan remaja (Weissman \& Helen, 1980). Dan lagi, peneliti sebelumnya menemukan bahwa, analisis paparan perkawinan menunjukkan bahwa selektivitas sosial dapat mendorong efek negatif kohabitasi (Guetto \& Nazareno, 2019). Serta adanya masalah sosial seperti stress, meningkatnya kriminalitas, pengangguran, kenakalan remaja diakibatkan dari hubungan sosial masyarakat dan perkembangan pola kehidupan akibat dampak berkembangnya komunitas masyarakat yang tak terkendali (Fajarini, 2019). Penelitian lanjutan berikutnya menemukan bahwa beberapa bukti bahwa efek migrasi selektif dimoderasi oleh integrasi kebijakan atau pengaturan pelacakan dalam sistem pendidikan di tujuan negara merupakan factor utama penyebab keseimbangan dalam hubungan keluarga dan masyarakat ( $G$ \& Anthony, 2018). Dan juga, hubungan antara perilaku sosial anak-anak dan status sosial mereka adalah kompleks. Popularitas peer group anak-anak telah terhubung dengan kepatuhan mereka terhadap aturan sosial, keramahan dan interaksi prososial (Dodge, 1983), (C \& Lagerspetz , 1996). Proses integrasi generasi pertama dan kedua sangat bervariasi di antara para migran dari berbagai negara asal dan antar negara tempat mereka bermigrasi. Satu domain integrasi menyangkut pencapaian pendidikan anak-anak dari imigran: adalah anakanak generasi kedua dari para migran yang dirugikan dalam sistem pendidikan dibandingkan dengan anak-anak dari populasi mayoritas di tuan rumah negara? Beberapa kelompok, seperti migran Asia ke AS, diketahui memiliki kinerja yang sangat baik dibandingkan dengan populasi mayoritas, sementara yang lainnya kelompok, seperti anak-anak dari pekerja migran Mediterania ke Eropa dari 1960-an-1970-an, jauh lebih buruk (Heath, 2008). Salah satu sumber potensial dari perbedaan mencolok antara kelompok imigran di seluruh berbagai negara hampir tidak dibahas dalam literatur komparatif: selektivitas populasi migran. Sejumlah studi satu negara telahmenunjukkan bahwa emigran dipilih secara positif pada pencapaian pendidikan dibandingkan dengan homestayers (Bertoli, et al., 2013) (Feliciano, 2005) and (Ichou, 2014). serta selektivitas migrasi untuk sejumlah besar negara membawa dampak yang signifikan positif, tetapi perlu memeriksa konsekuensi untuk integrasi ke dalam sistem pendidikan anak-anak imigran serta kehidupan sosial (Brucker \& Defoort, 2009) and (Belot \& Hatton, T.J, 2012). Dari beberapa peneliti tersebut diatas menyimpulkan bahwa hubungan sosial masyarakat sangat erat hubungannya dengan pola hidup yang ada di keluarga, sehingga control orang tua dalam menentukan kebijakan tempat tinggal dan pergaulan masyarakat menjadi penentu utama dalam keseimpangan dan pengaruh positif dalam beraktifitas.

Masalah keluarga berarti sejenis hubungan bermasalah antara anggota keluarga yang pada gilirannya menyebabkan ketegangan, apakah masalah ini disebabkan oleh kesalahan anggota keluarga atau dua pihak utama, dan sering terjadi pertengkaran dan perbedaan antara orang tua, atau antara anak-anak atau antara anak-anak dan orang tua mereka. Krisis keluarga adalah sesuatu yang membuat seseorang berjuang untuk solusi masalah yang berbeda dan tidak biasa (Hill, 1956). Pecahnya hubungan keluarga yang memaksa reorganisasi pola keluarga tidak hanya merupakan krisis keluarga tetapi juga merupakan ancaman bagi kesatuan keluarga. Penyebab Masalah Keluarga: Hubungan interpersonal yang tidak memadai, tekanan keanggotaan kelas, tekanan ekonomi dan lainnya, aib sosial adalah penyebab krisis keluarga dan melibatkan ancaman bagi organisasi keluarga terhadap bentuk dan strukturnya. organisasi keluarga terhadap bentuk dan strukturnya.Efek Krisis:Setiap krisis merupakan pukulan bagi keluarga. Semua anggota dipengaruhi secara kolektif. Itu menciptakan kesedihan, kemarahan atau kesedihan bagi anggota keluarga dan mereka memainkan peran mereka tanpa antusiasme. Krisis memiliki efek jangka pendek dan jangka panjang pada keluarga. Perencanaan yang bijaksana, pengorbanan sifat anggota keluarga, kemampuan beradaptasi keluarga, integrasi 
keluarga, hubungan kasih sayang di antara anggota keluarga, penyesuaian perkawinan yang baik antara suami dan istri, hubungan orang tua-anak yang saling berhubungan, penasihat keluarga, jenis pengambilan keputusan kontrol, partisipasi istri dalam kegiatan di luar rumah dan pengalaman sukses sebelumnya dengan krisis adalah semua faktor penting dalam memungkinkan keluarga untuk menyesuaikan diri dengan krisis. Istri rumah harus siap secara mental untuk menghadapi situasi dengan berani. Dia harus menyerap kejutan yang timbul dari masalah seperti itu untuk menjaga anggota keluarga.Mayoritas masalah keluarga tidak berada di bawah kendali keluarga. Mereka harus bertahan dengan kesabaran. Perencanaan yang matang, kematangan emosi dan kemampuan untuk menyesuaikan diri dengan keadaan baru akan membantu menghadapi situasi dengan berani. Ini bukan tugas yang harus diselesaikan oleh satu individu. Seluruh keluarga perlu diatur ulang, sebagai upaya koperasi dengan moto "Bersatu kita berdiri dan membagi kita semua jatuh".

Dari permasalahan yang ada diatas penulis berkeinginan untuk mengetahui permasalahan penyebab utama dari pengaruh sosiologis kemasyarakatan terhadap karakter keluarga, yang mana rumusan masalahnya adalah: Apa pneyebab utama sosiologis kemasyarakatan terhadap pola hidup dan karakter keluarga?. Tujuan dalam penelitian ini yaitu penulis berkeinginan untuk mengetahui penyebab utama munculnya pengaruh sosiologis kemasyarakatan yang berdampak terhadap karakter keluarga serta dampaknya pada kehidupan bermasyarakat. Dua keluarga dari desa Bendogerit kota Blitar sebagai subjek penelitian yang di pilih menggunakan pola pemilihan mandiri karena penulis menganggap bahwa peserta dan lokasinya layak menjadi subjek yang akan diteliti sesuai dengan topik pembahasannya.

\section{METODE}

Case study dalam pendekatan penelitian qualitative digunakan dalam penelitian ini. Yang mana dua keluarga dari desa bendogerit kota Blitar sebagai audiences yang di pilih menggunakan pola pemilihan mandiri karena penulis menganggap bahwa peserta dan lokasinya layak menjadi subjek yang akan diteliti sesuai dengan topik pembahasannya. Dan lagi, penulis menerapkan system interview via whatsapp dengan mengirimkan file interview sheet dalam bentuk PDF dikarenakan kondisi pandemic covid 19 sekarang ini.kemudian dalam menganalisa hasil data yang telah terkumpul, penulis melakukan beberapa hal untuk sampai merumuskan hasil akhir yang didapat yaitu: 1) Mengatur dan menyiapkan data untuk dianalisis; 2) membaca atau melihat semua data; 3) Mulai koding semua data; 4) menghasilkan deskripsi dan tema; 5) mendeskripsikan sebagai temuan penelitian ini (Creswell, 2018).

Dalam penjalankan penelitian, penulis melakukan langkah langkah sebagai berikut mulai tahap awal sampai tahap akhir atau interpretasi hasil penelitian yaitu : 1) menentukan audiences serta lokasi penelitian yang disesuaikan dengan tema; 2) koordinasi dengan dua keluarga yang dipilih sebagau subjek penelitian sebagai langkah awal perkenalan penelitian; 3) pengambilan data melalui interview sheet yang dikirimkan melalui Whatsapp group; 4) mengolah data hasil interview melaui tahapan yang sesuai dengan pendekatan case study; dan 5) membuat interpretasi setelah pengolahan data secara lengkap sebagai hasil akhir penelitian.

\section{HASIL DAN PEMBAHASAN}

Pada tahap pemilihan lokasi dan subjek dalam penelitian, penulis menentukannya sesuai dengan tema penelitian dan kondisi yang didasarkan pada pola pemilihan mandiri / self-selection dengan cara menghubungi via Whatsapp pada keluarga yang dipilih. Diskusi penentuan peserta dan lokasi dapat mencakup empat aspek yang diidentifikasi oleh Miles dan Huberman (1994): (a) pengaturan (yaitu, di mana penelitian akan berlangsung), (b) aktor (yaitu, siapa yang akan diamati atau diwawancarai ), (c) peristiwa (yaitu, apa yang akan diamati atau diwawancarai oleh para aktor), dan (d) proses (yaitu, sifat peristiwa yang berkembang yang dilakukan oleh para aktor dalam lingkungan) (Miles \& Huberman, 1994). Kemudian dilanjutkan dengan 
koordinasi dengan dua keluarga sebagai langkah awal perkenalan penelitian yaitu penulis memberikan informasi terkait pola dalam penelitian dan mengenalkan topik sebagai pedoman keluarga mengaplikasikan dalam kehidupan berkeluarga dan bermasyarakat sehingga mereka tidak mengalami hambatan dalam melakukan uji coba dan proses pengambilan data akan mengahasilkan luaran yang sesuai dengan tujuan penelitian. 2 minggu setelah adanya pengenalan dari penulis terhadap dua keluarga tersebut, penulis memulai membagikan interview sheet dan dikirimkan melalui Whatsapp untuk proses pengambilan data.

Tabel.1 Interview dan jawaban

\begin{tabular}{|c|c|c|c|c|c|}
\hline NO & MONITORING DIRI & \multicolumn{2}{|c|}{ KELUARGA A } & \multicolumn{2}{|c|}{ KELUARGA B } \\
\hline & & YA & TIDAK & YA & TIDAK \\
\hline 1 & Saya perhatian pada hubungan tetangga & $\mathrm{V}$ & & $\mathrm{V}$ & \\
\hline 2 & $\begin{array}{l}\text { Saya memperhatikan lokasi dan keadaan } \\
\text { sekitar disaat pemilihan lokasi tempat }\end{array}$ & V & V & & V \\
\hline 4 & $\begin{array}{l}\text { Saya selalu mengikuti Sunnah agama } \\
\text { dalam kehidupan bersosial masyarakat } \\
\text { Saya penuh perhatian terhadap }\end{array}$ & V & & & V \\
\hline 5 & $\begin{array}{l}\text { lingkungan sekitar } \\
\text { Semua aktifitas sosial saya dipengaruhi }\end{array}$ & & $\mathrm{V}$ & & $\mathrm{V}$ \\
\hline 6 & $\begin{array}{l}\text { oleh pola kehidupan dalam tetangga } \\
\text { Saya dan keluarga tidak perduli terhadap }\end{array}$ & & $\mathrm{V}$ & V & \\
\hline 7 & $\begin{array}{l}\text { lingkungan dan tetangga sekitar } \\
\text { Saya suka hidup berkelompok bersama } \\
\text { tetangga }\end{array}$ & V & & V & \\
\hline 9 & $\begin{array}{l}\text { Saya sangat memperhatikan pendidikan } \\
\text { keluarga } \\
\text { Saya selalu melarang anak anak saya }\end{array}$ & V & V & V & V \\
\hline 10 & $\begin{array}{l}\text { bersosialisasi terhadap tetangga } \\
\text { Saya selalu memperhatikan waktu } \\
\text { bermain anak saya }\end{array}$ & & $\mathrm{V}$ & & $\mathrm{V}$ \\
\hline
\end{tabular}

Setelah proses interview selesai dan hasil nya dikirimkan ke penulis, kemudian langkah selanjutnya mengolah data hasil interview dengan cara mengelompokkan sesuai dengan pertanyaan penelitian untuk membagikan sesuai dengan tujuan penelitian sehinnga penulis akan dengan mudah dalam mengambil kumpulan jawaban sebagai gambaran interpretasi hasil penelitian. Hasil interview bisa disimpulkan bahwa kedua keluarga diatas memiliki kesamaan yaitu 1) perhatian pada hubungan tetangga, 2) tidak memperhatikan lokasi dan keadaan sekitar disaat pemilihan lokasi tempat tinggal, 3) Semua aktifitas sosial mereka dipengaruhi oleh pola kehidupan dalam tetangga, 4) mereka suka hidup berkelompok bersama tetangga, 5) sangat memperhatikan pendidikan keluarga, 6) tidak pernah melarang anak anak mereka bersosialisasi terhadap tetangga, dan 7) tidak pernah memperhatikan waktu bermain anak saya. Dari kesamaan data dalam merespon isi pertanyaan interview pada penelitian ini bisa diambil keutamaan kesimpulan akhir yaitu meskipun kedua keluarga tersebut diatas sangat perhatian terhadap pendidikan anak mereka dalam tujuan hidup kedepan dan selalu berperilaku sosial yang harmonis terhadap tetangga sekitar, tetapi mereka terlalu membiarkan pola kehidupan bermasyarakat disekitarnya mempengaruhi kehidupan keluarga mereka, karena mereka tidak perduli dengan masalah yang ada di lingkungan sekitar dan terlalu memberikan keleluasaan terhadap anak anak mereka dalam bersosialisasi terhadap teman dan tetangga dan para orang tua tidak memberikan batasan dan pengawasan secara ketat, oleh karena itu perjalanan pola kehidupan anak mereka tidak terkendali dan memiliki efek negative terhadap karakter 
kesopanan dan perubahan cita cita serta kecenderungan menimbulkan banyak permasalahan dalam keluarga serta lingkungan seperti : perkelahian, minum minuman keras, prostitusi, serta kejahatan lokal.disisi lain dalam keluarga, mereka kehilangan kerukunan dan kehidupan tidak terlalu harmonis dikarenakan kesemuanya disibukkan dengan urusan lingkungan yang berakibat ketidakpedulian keakrapan dalam keluarga.

\section{KESIMPULAN}

Karakter Keluarga sangat dipengaruhi oleh Pengaruh Sosiologis Kemasyarakatan dikarenakan kehidupan bermasyarakat dalam pergaulan bersosial secara siknifikan merubah keteguhan serta kemandirian dalam keluarga serta kurangnya kesadaran diri dalam mempertahankan keteguhan serta kemandirian dalam menentukan pola hidup mandiri mereka juga memiliki peran yang sangat riskan dalam mempengaruhi keteguhan sebuah keluarga, dan lagi factor perhatian orang tua terhadap anak merupakan factor lain yang menyebabkan ketidak seimbangnya kehidupan mereka sebab masalah yang ada terhadap lingkungan sekitar diawali oleh banyaknya anak yang kurang mendapatkan perharian orang tua serta dukungan lingkungan masyarakat.

Diharapkan contoh pola kehidupan keluarga dalam menjalani pola kehidupan bermasyarakat diatas menjadi gambaran dan contoh bagi keluarga lain khususnya keluarga baru dalam menentukan pilihan lokasi tempat tinggal baru serta dalam menjalankan pola kehidupan bersosial masyarakat mereka. Serta bagi orang tua dan guru, gambaran diatas sangatlah baik bagi penerapan pengawasan yang ketat terhadap perilaku anak mereka dalam memilih pergaulan serta aktifitas sehari hari mereka sehingga pengaruh buruk yang dibawa oleh sosial sekitar tidak terbawa pada anak anak mereka ke sekolah atau dalam keluarga. Dan lagi bagi pemerintah, gambaran hasil penelitian diatas sangatlah berguna sekali bagi pemangku kebijakan dalam perumusan kebijakan daerah dalam upaya pencegahan kenakalan remaja serta penerapan hidup sehat bermasyarakat.

Dari uraian diatas secara keseluruahan dapat disimpulakan bahwa adanya hubungan yang erat antara kehidupan dalam keluarga dan sosiologis kemasyarakatan pada perubahan pola kehidupan bermasyarakat secara luas.dan lagi factor keluarga menjadi penentu dari semua pola perubahan yang terjadi pada rartai hubungan sosial bermasyarakat.

\section{DAFTAR RUJUKAN}

Belot, M. V. K. \& Hatton, T.J, 2012. Immigrant selection in the OECD. The scandinavian Journal of Economics, 114(4), pp. 1105-1128.

Bertoli, S., Fernandez, H. M. \& Ortega, F, 2013. Crossing the border: self selection, earnings and individual migration decisions. Journal of DEvelopment Economics, Volume 101, pp. 75-91.

Brucker, H. \& Defoort, C., 2009. Inequality and the self-selection of international migrants: Theory and new evidence. International Journal of Manpower, 30(7), pp. $742-764$.

Creswell, J. w., 2018. Research design: qualitative, quantitative, and mixed method approaches. Fifth Edition ed. London: SAGE Publications, Inc.

C, S. \& Lagerspetz , K., 1996. Bullying as a group process: Participant roles and their relations to social status within the group, s.l.: s.n.

Dodge, K. A., 1983. Behavioral antecedents of peer social status, s.I.: s.n.

Fajarini, U., 2019. Patologi sosial dan dampaknya terhadap remaja. Jurnal Harkat : Media Komunikasi Gender, Volume 15, pp. 1-9.

Feliciano, C., 2005. Does selective migration matter? explaining ethic disparities in educational attainment among immigrants' children, s.l.: Demography.

G, H. \& Anthony, H., 2018. Selectivity of migration and the disadvantages of secondgeneration immigrants in ten host societies. Eur Journal Population, Volume 35, pp. 347-378. 
Guetto, R. \& Nazareno, P., 2019. Family arrangements and children's educational outcomes: Heterogeneous penalties in upper secondary school.. Journal of Population sciences, 140(35).

Heath, A. F., 2008. The second generation in western europe : education, unemployment, and occupationnal attainment, s.l.: Annual Review of Sociology.

Hill, R., 1956. Problem of communication between husband and wife on matters relating to family limitation. Human Relations, Volume 9, pp. 207-215.

Ichou, M., 2014. Who they were there: Immigrants' educational selectivity and their children's, s.I.: European Sociological Review.

Miles, M. B. \& Huberman, A. M., 1994. Qualitative data analysis: A source book of new methods. Thousand Oaks, CA: SAGE.

Rubington, E. \& Weinberg, M., 2010. The study of social problem : Seven perspectives. 7 ed. New York: Oxford University Press.

Weissman, M. M. \& Helen, O., 1980. Children's symptom and social functioning selfreport scales. The Journal of Nervous and Mental Desease, 168(12). 